\title{
A CONTENT ANALYSIS OF WIRED MAGAZINE IN TERMS OF SELF- TRACKING DEVICES
}

\author{
Serefraz AKYAMAN \\ Sakarya University, Turkey \\ serefraz@sakarya.edu.tr \\ Tuğba AYAS ÖNOL \\ Sakarya University, Turkey \\ ayas@sakarya.edu.tr
}

\begin{abstract}
In the digital era that we live in now it is possible to gather biological and biographical data of an individual by wearable digital health and activity-tracking devices. The phenomenon is known as selftracking and it intends to expand individual's self-knowledge and as a result to improve both the physical and psychological health. By self-tracking applications that digital health and activitytracking devices provide now we can measure diverse biodata from heart rate, body fat percentage and pain levels to miles run, calories eaten and even to mood and happiness levels. The aim of this paper is the analysis of growing digitalized self-tracking trend through a content analysis of Wired magazine. This well-known design and technology magazine monthly publishes in print and online technology related articles on how emerging technologies affect culture, economy and politics and it reaches online more than 30 million people each month through wired.com, digital edition. This present study, carries out a content analysis of all the issues until December 2016 through the term 'self-tracking' and also two other closely related terms: 'quantified self' and 'lifelogging'. In the analysis, the usage period and popularity of these three terms; their relation network with the main topics and the sub-topics of the magazine are examined. By this analysis, the study presents the scope and relevance of the rising trend of self-tracking technologies from the birth of this trend.
\end{abstract}

Keywords: Self-tracking, Quantified self, Lifelogging, Content analysis, Trend analysis

\section{KISŞISEL TAKİP CIHAZLARI BAĞLAMINDA WIRED DERGISSINIIN BİR İÇERIKK ANALIZİ}

\section{$\ddot{O Z Z}$}

İçinde yaşadığımız dijital çağda giyilebilir dijital sağlık gereçleri ve aktivite izleyici gereçler sayesinde bireyin biyolojik ve biyografik verilerini edinmek mümkündür. Bu olgu kişisel takip adıyla bilinir ve bireyin kendine dair bilgisini arttırmayı ve bu sayede de hem fiziksel hem de psikolojik sağlığını iyileştirmeyi hedefler. Sağlığı ve aktiviteleri izleyen araçların sunduğu kişisel takip uygulamaları sayesinde nabız, vücut yağ yüzdesi ve ağrı seviyelerinden kaç kilometre koşulduğu, kaç kalori alındığı ve hatta duygu durumu ve mutluluk seviyelerine kadar birçok biyolojik veriyi ölçebiliyoruz. Bu çalışmanın amacı gittikçe büyüyen bu dijital kişisel takip trendi bağlamında Wired dergisinin bir içerik analizini yapmaktır. Hem basılı hem de online olarak ayda bir basılan bu tasarım ve teknoloji dergisi gelişen teknolojilerin kültürü, ekonomiyi ve politikayı nasıl etkilediği konusunda teknoloji tabanlı makaleler yayımlar ve online olarak wired.com adresinden ayda 30 milyon insana ulaşır. Bu çalışma Wired dergisinin Aralık 2016 tarihine kadar olan tüm sayılarında "self-tracking" (kişisel takip) terimi ve bu terim ile yakından ilişkili olan "quantified self" (nicel benlik) ve "lifelogging" (yaşam günlügü) terimlerini içeren bir içerik analizi ortaya koymaktadır. Analizde bu üç terimin kullanım süreleri ve popülariteleri ve derginin ana konuları ve alt başlıkları ile olan ilişkileri araştırılacaktır. Böylece 
yükselen bir trend olan kişisel takip teknolojilerinin kapsamı ve alaka düzeyi bu trendin doğuşundan itibaren ele alınacaktır.

\section{Anahtar Kelimeler: Kişisel Takip, Nicel benlik, Yaşam günlü̆̆̈̈, İçerik analizi, Trend analizi}

\section{INTRODUCTION}

Keeping track of things that matters to us or recording personal data are not unfamiliar human deeds. For centuries, people used non-digital technologies in order to measure their health or monitor and the appearance of their bodies. Yet, the developments in digital technologies that can enable collection, calculation and demonstration of personal data digitally is crucial in the emergence of new phenomena called self-tracking and life logging in the way today (Lupton, 2014; Lupton 2016). Even though selftracking and lifelogging can be seen simple digital versions of diaries, the potential evolution of these practices promises much more than basic monitoring. The fundamental reason behind these practices lies in the fact that compared to tasks of the daily life of the past before computerization, today's network of relationships established throughout the day creates an overwhelming schedule for any individual to follow. Right at this moment, with the effortless and highly accurate recording mechanisms, self-tracking devices emerged as an efficient trend of digitalized tracking. Thus, it can also be claimed that self-tracking devices arise from the intersection of the multitude of requirements and obligations generated between work and life and the finite capacity of human memory to accomplish these tasks thoroughly.

The self-tracking trend started early in the health industry. A multitude of wearable sensors is becoming widely available and these sensors enable us to measure many aspects of our health, as well as to receive immediate feedback about how we are performing. The products developed upon these wearable sensors basically starts to know us and intelligently collect data about us or interrupt our day for the sake of optimal health and productivity outcomes for us.

Lupton (2016) notes that in recent years detailed quantifiable data have gained value over the value of one's other forms of information about life, health and well-being. While the support of the technology so far has simply been reminiscent of what to do (remembering future events), now by the new selftracking technologies one can also store and organize personal information such as physical activity, amount of water consumption, sitting- time, etc. Not surprisingly, various industries conducted research and development projects on this new rising trend and as a result of these researches, products designed to have similar intends with self-tracking are seen in the industries of health, fashion and furniture.

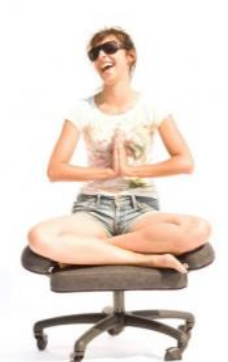

(e)

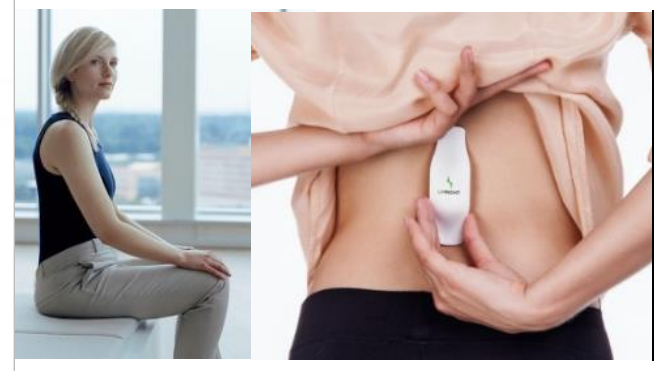

(a) (b)

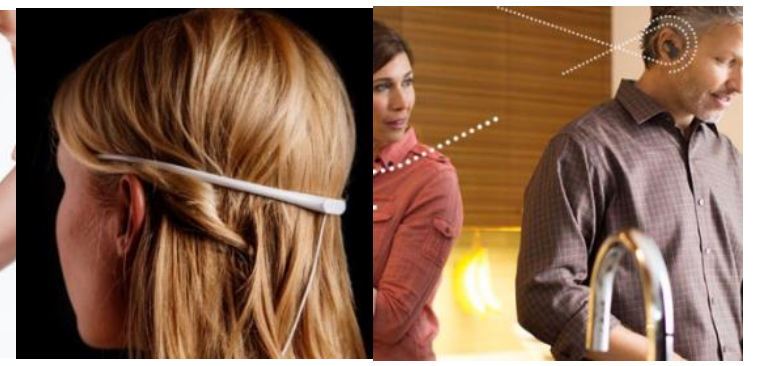

(c) (d)

1. Figure 1. Examples for emerging trend via three times rule

a: The Sukhasana Yoga Chair b: FysioPal posture corrector c: UpRight posture corrector d: Elf mmmit Stress Relief Headbang e: Soundhawk's Smart Listening System

The most interesting and curious aspect of the self-tracking phenomenon is the applications that are developed for the possible new areas of human life. In 2016 The National Institute of Mental Health (NIMH) have listed current trends in app development in self-tracking practice as follows: 
- Self-management apps

- Apps for improving thinking skills

- Skill-training apps

- Illness management, supported care

- Passive symptom tracking

- Data collection

These applications are performed by mobile digital devices. The devices connected to the Internet have facilitated real-time, more detailed data measurement and monitoring of bodily activities as well as the analysis, presentation and sharing of the data (Lupton, 2016). The digital tools, which are installed by sensors and microprocessors, are used to collect relevant data mostly quantitatively on various variables such as body functions, emotional states, sexual and social encounters, work efficiency, physical activities, geographical locations through movement, sound waves, temperatures etc.In some cases personal data can also be collected and displayed qualitatively using words, pictures, and objects (Lupton, 2016). Quantitative or qualitative data gathered is aimed to expand the self-knowledge and finally to contribute to the self-fulfillment adventure of an individual. For instance, to support healthrelated behavior change, collecting data about the body is essential for future conditions since it allows the individual to control himself/herself at the present time and in the future.

In addition to 'self-tracking' practice defined as monitoring, measuring and recording aspects of one's body, behavior and life; several terms like personal informatics, personal analytics, lifelogging and the quantified self are also introduced into the field (Lupton, 2016: 8). Personal informatics and personal analytics are terms often used in literature in the area of human-computer interaction (Lupton, 2016: 9). Both the notion of artificial intelligence and the concept of cyborg have been a source of inspiration for both the scientists and the cultural theorists who have written about the effects of computerized technologies on human configuration and subjectiveness (Lupton, 2012). The term lifelogging, which is regarded as the most rooted across self-tracking terms, emerged in the early days of personal computing (Sellen and Whittaker, 2010). It is considered as a heuristic collective term and known to refer to diverse types of self-tracking that range from health monitoring, detection of one's location to the measurement of productivity at work (Selke, 2016:1). Furthermore, according to Selke, lifelogging can basically be examined in four category: monitoring health, human tracking (Gps or radio cells), human digital memory and surveillance/sousveillance (2016).

As for the term quantified self, Gary Wolf and Kevin Kelly are first to suggest the term after they observed many people collecting data about themselves. Seeing this personal data collecting culture as a new trend they introduced the term 'quantified self' to describe this detailed digitalized self-tracking phenomenon. Later, in 2010 in his article published in The New York Times Wolf described the term self-tracking as 'self-knowledge through numbers' and this has become the motto of the movement called Quantified Self (QS). The Quantified Self (QS) is defined by Swan (2013) as 'any individual engaged in the self-tracking of any kind of biological, physical, behavioral, or environmental information.' For indicating the difference between the terms of QS and lifelogging Krynsky suggests to define the lifelogging as a form of transformation that allows all personal data to be collected digitally and to be researched or review while recognizing the QS movement as collection of raw data and the search for ways to make life better by making associations over them (2010).

The U.S. National Intelligence Council referred the term QS in the literature as 'the internet of things' and defined as "the general idea of things, especially everyday objects, that are readable, recognizable, locatable, addressable, and controllable via the Internet - whether via RFID, wireless LAN, wide-area network, or other means". The term has been instrumental in the emergence of these devices, which are capable of constantly activation and real-time data exchange and evaluation.

This brings about another aspect of digital tracking. Most of the time digital self-tracked data are stored in the cloud-based computing system that only developers can access and use for their purposes 
(Lupton, 2016). However, there is always a risk of exposure and surveillance via the data stored in cloud systems.

The French sociologist Gabriel Tarde commented about the further development of society and social statistics in 1890;

a time may come when upon the accomplishment of every social event a figure will at once issue forth automatically, so to speak, to take its place on the statistical registers that will be continuously communicated to the public and spread abroad pictorially [...]Then, at every step, at every glance cast upon poster or newspaper, we shall be assailed, as it were, with statistical facts, with precise and condensed knowledge of all the peculiarities of actual social conditions (Tarde, 1903; quoted also in Gertenbach, Mönkeberg, 2016).

Tarde's early prediction and what seems rather to be dystopian view is actualized with development of technology through the sharing experience of the mentioned self-tracking practices above. In the 1980s, the attention of social and cultural theorists began to focus to the relationship between the human body and computer technology. In this sense one of the earliest examples of lifelogging was Steve Mann's work, the EyeTap project in the early 1980s. Since 1994, he has started to broadcast his life on the website 7 days 24 hours, and over time, this process was opened up to instant viewers and moved to an interactive level where the audience can be involved. Also in the mid-80s Mark Schulze, a mountain biker, created the first helmet cam by rigging a video camera to a portable video recorder (Winchester, 2015). In 2004, the first GoPro was launched that enables to take adventurous in time photographs. Another study in the early 2000s that attracted attention was Microsoft's MyLifeBits project, where researcher Gordon Bell digitally captured a lifetime's photos, messages and work, while colleagues designed software to navigate it (Stuart, 2014).

Ultimately the core of the lifelogging movement was the idea of "creating a better human" (Gertenbach, Mönkeberg, 2016). At present tracking and logging are performed by mobile phones which can collect and keep large amount of data and generally process the data about how we use that device or our action patterns in a specific area like walking or running through GPS or radio cells. Since the advent of smartphones and tablets, numerous commercial applications have been created, many of which are directed at consumers who wish to track or monitor their exercise, dietary or sleeping habits, pulse, or even more private personal data such as fertility or menstruation cycles. It is possible to discuss the usability of applications that compile data about more than one area and require the individual to take and engrave measurements which obtained manually (Lupton, 2013). The relationship between an increase in the efficiency of an activity that has been going on for such a long time and the production of devices capable of automatically processing data in a specific area and without being aware of the individual is worth investigating. The relationship of data collecting and the needs in software has led the emergence of new and specialized products for each specified activity, products that aim to bring us to a better level both physically, mentally and emotionally.

Some organizations, private institutions and even the governmental state encourage the use of healthcare applications more commonly through health promotion campaigns. This is the effort mainly for translating someone's potential use into meaningful data through recorded information about their bodily activities or habits, etc. By this way, constant reminders for us to be in health-promoting behaviors are created (Lupton, 2012).

According to Department of Media and Information in Apple app store and Google play store, currently there are more than 97,000 health-related apps available in the health and fitness category and every month more than 1000 items are added, with about 1000 more being created every month. It is anticipated that every year this amount will add up to $25 \%$ more new health related applications. It is anticipated that they will be added by $25 \%$ every year 
(Peng et al., 2016). It should also be noted that besides the applications used only on mobile phones, many other customized products are designed today. These products include smartwatches, wristband sensors, wearable sensor patches, artificial reality-augmented glasses, brain computer interfaces, wearable body metric textiles (Swan, 2013).

Figure 2. Self-tracking gadget examples

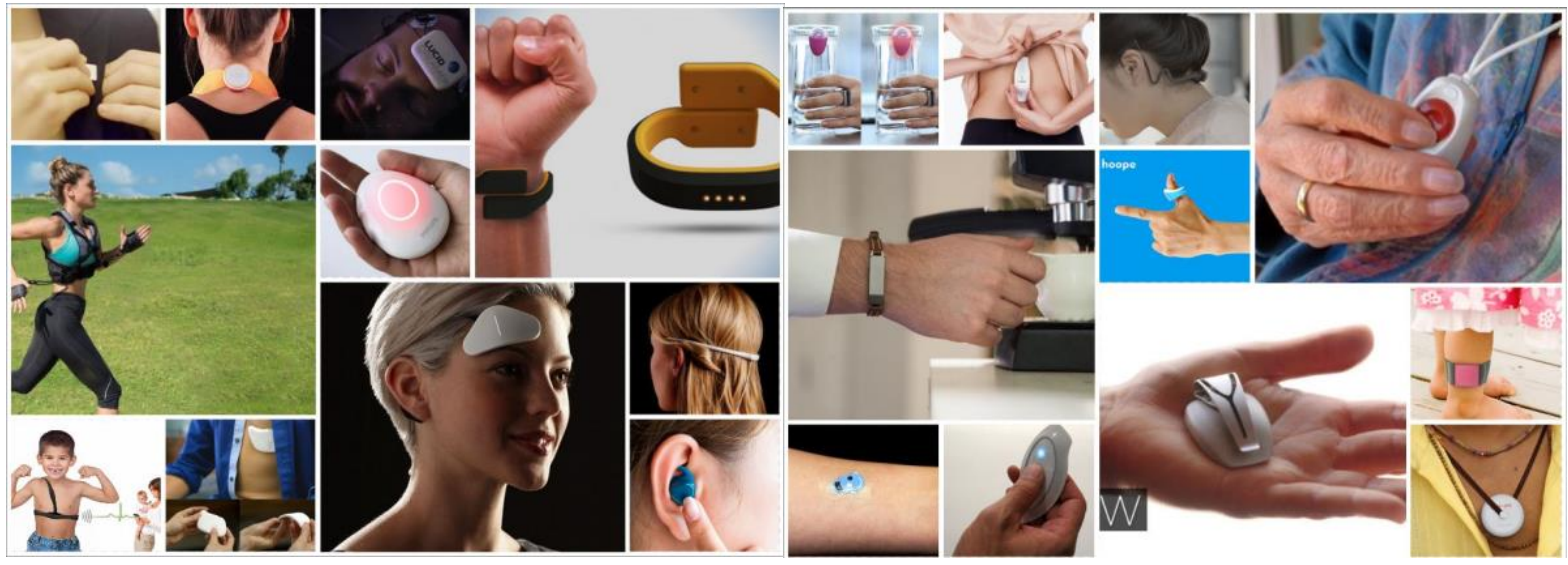

Among these products wearable technologies are also quite varied. Products that specialize in a number of areas are available and usable via a smartphone or computer program. These devices present the resulting data to its user in the form of figures, texts, diagrams, notifications and alerts. The wearable products intelligently collect data about users and if it is programmed to warn the user, it interrupts daily life for optimal health and productivity outcomes. Since the data obtained from the users are also different from each other, those devices are ultimately customized for each person. Apps and gadgets use the device's built-in sensors to collect information on a user's typical behavior pattern, promise to improve memory or thinking skills. These behavior patterns have begun to vary in the following forms: physical health (how energized/healthy you are), emotional health (how you are doing in general, whether you are feeling positive vibes), and mental health (how efficiently you could focus today, how creative you are). There are currently 505 registered tools listed on the Wolf's website, quantifiedself.com that serve this purpose. (Quantified self-guide 2017). Devices that are designed for this purpose mainly deal with some output obtained by measuring (conditions, symptoms, genome, biomarkers, behavior, environment) the actions (research, treat, intervene, experiment, track, measure) of a person. Swan (2009) lists these outputs as: self-expression, enhancement, prevention, normalization, improvement and cure.

\section{Research Method: Content Analysis}

Wired Magazine is an American magazine establishment published both in print and online monthly. It publishes on all aspects of technology and on the effects of emerging technologies on today's culture, economy and politics (Wired). As stated before Wired magazine reaches more than 30 million people each month through wired.com, digital edition. Also it is possible to define Wired Magazine as a medium in which industry-academia and users come together and feed each other reciprocally. Moreover, the magazine has contributed significantly both to the emergence and spread of the digitalized self-tracking trend in terms of discussions of efficiency of related products. The goal of the study is to present the scope and relevance of the topic of self-tracking technologies in relation to the main and sub-topics of Wired magazine. In order to achieve this, a content analysis of Wired Magazine from the first January 1993 volume to December 2016 volume was conducted. The terms self-tracking, quantified self and lifelogging were accepted as key words and used to analyze the articles published in the magazine.

\section{RESULT AND DISCUSSION}


First of all, in online database of wired.com there are 109 results for "quantified self", 23 results for "self-tracking, and 13 results for "lifelogging" terms (see Table.1). Overall, over four times more articles are written on quantified self than the on the other two terms.

Table 1. Year based relevant article quantity

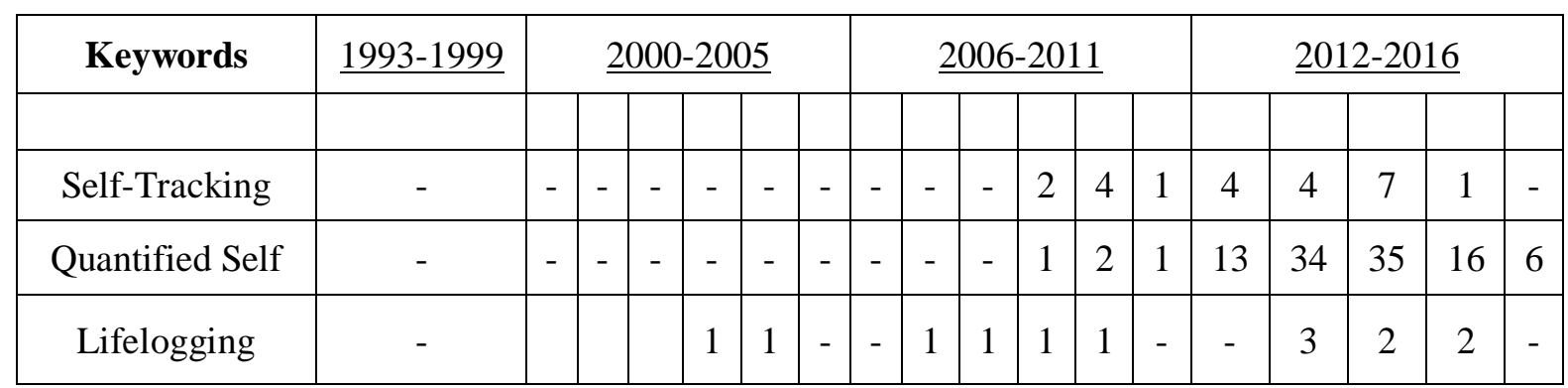

When the articles are examined with respect to terms similar to self-tracking in content, it is observed that in the articles published in the first years, the above mentioned three terms are embedded in and finally in next issues follows from the concepts of "tracking/tracker" and "monitoring". Overall, up to date there are 1070 results in health monitoring, 1368 results for tracker, and 2007 results for self-track keywords. Thus, it can be derived that the three terms focused in this study goes back to the issues before 2000 .

Table 2. Time- frequency of occurrence of the keywords self-tracking, quantified self and lifelogging through Google Trends.
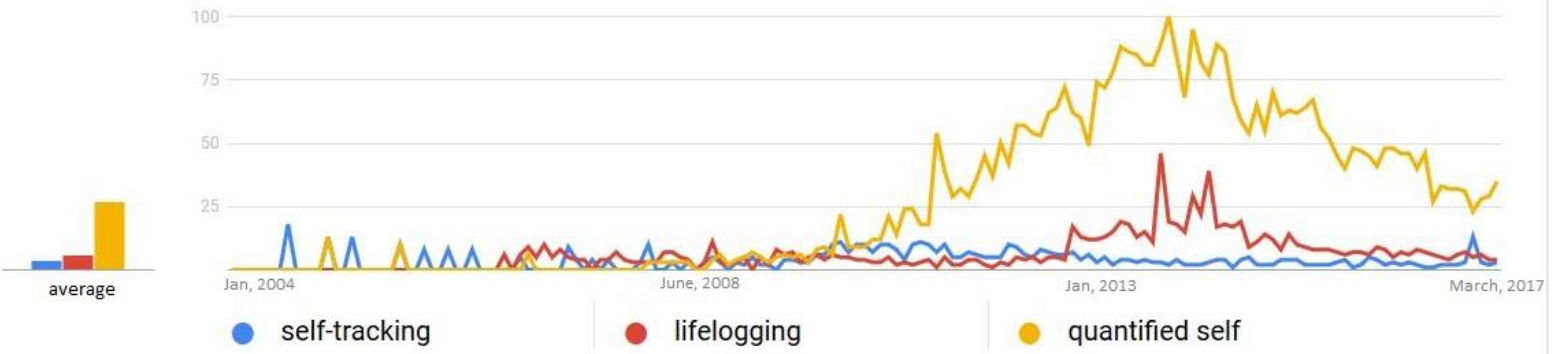

As an additional sub-search, by analyzing the searches performed on the three selected keywords on Google Trends, it can be seen that the term "self-tracking" first emerges in 2004 and especially after 2009, the amount of searches performed by the term "quantified self" have increased considerably. Comparing this increase to the amount of the articles in Wired magazine that involves the term quantified self, one can register a similar escalation in number. Furthermore, in parallel with the magazine, there is also an increase in the search frequency of the term lifelogging between the years 2013-2014. As a side note, this also supports the efficiency of the Wired magazine in keeping up with the rising trends.

It can be seen that the articles on these three key terms have started to be written since 2009. This is also closely related to the technological developments since 2000 and on when self-tracking products and applications have started to be launched. For instance, in the late 2000s, and Apple and Nike's collaboration on the Nike+iPod fitness tracking device gave consumers a way to use their existing technology to keep fit (Winchester, 2015). In 2009 the activity tracker of Fitbit Company was sold. In 2011 Fitbit improved the existing product by adding an altimeter, a digital clock and a stopwatch, and since that day, they are still improving their products. In the same year in November, first generation of UP by Jawbone, an activity tracker released. As of 2012, the use of the terms lifelogging, selftracking and quantified self as keywords in the articles are observed to increase in number. 2012 
marked a year of unprecedented investments and research into the intersection of technology and fitness with products such as Nike Fuelband, The Fitbit One, and The Fibit Zip. 2012 was the year of crowd funding, and the two biggest sites (Kickstarter and Indiegogo) each featured activity trackers among their most successful products. From this date on, it is observed that the products are diversified, new features are added and the accuracy rate in the measurement increased.

Among these three terms in question, as seem from the findings in Table1, the term quantified self is far more popular in the design related area. The first article about quantified self is entitled "Know Thyself: Tracking Every Facet of Life, from Sleep to Mood to Pain, 24/7/365". In the article Gary Wolf (2009), who is one of the kickstarter of 'Quantified Self' movement with Kevin Kelly, a cofounder of Wired magazine, conducts a mini research about himself by tracking his sleep, exercise, blood pressure, mood, caffeine and alcohol consumption. He states that since 2007, in the last two years before this famous article, they noticed that their acquaintances start to 'extract streams of numbers from ordinary human activities'. After a thorough observation they announces this habit as a new personal data culture: 'Self-knowledge through numbers'. This new data culture indicates that it is becoming easier to self-track with new tools. In the same issue, as Wolf's genuine contribution to the concept, Wired magazine published four articles on quantified self-tracking focusing on specific areas: running, exercise, health and nutrition (Lupton, 2016).

As a next step in this present study, 92 articles in the "quantified self" search, published between October 2016 and June, 2009 are reviewed in more detail. It is realized that the articles are tagged with some key words pointing out the topic by the authors. The key words that are specific to this search are as follows: design, business, gear, science, magazine, security (Table 3).

Table 3. Article keywords and usage percentage for 'quantified self' search

\begin{tabular}{|c|c|c|c|c|c|c|c|c|}
\hline & \multicolumn{7}{|c|}{ Article Topic } \\
\hline & Design & $\begin{array}{c}\text { Busines } \\
\mathrm{s}\end{array}$ & Gear & $\begin{array}{c}\text { Scienc } \\
\mathrm{e}\end{array}$ & $\begin{array}{c}\text { Magazin } \\
\mathrm{e}\end{array}$ & $\begin{array}{c}\text { Securit } \\
\mathrm{y}\end{array}$ & $\begin{array}{c}\text { Sponsore } \\
\mathrm{d}\end{array}$ & $\begin{array}{c}\text { Undetermine } \\
\mathrm{d}\end{array}$ \\
\hline Quantity & 21 & 18 & 17 & 6 & 3 & 1 & 19 & 7 \\
\hline $\begin{array}{c}\text { Percentag } \\
\mathrm{e}\end{array}$ & $\begin{array}{c}22,80 \\
\%\end{array}$ & $19,50 \%$ & $\begin{array}{c}18,40 \\
\%\end{array}$ & $6,50 \%$ & $3,20 \%$ & $1 \%$ & $20,60 \%$ & $7,60 \%$ \\
\hline
\end{tabular}

In addition, some articles are not marked with any keywords, and some articles are marked as sponsor content. In order to observe the three main terms of this study in detail we suggest 10 tags (above in the top row of Table 4) to cross examine with the key words given in Wired magazine articles.

Table 4. Article keywords and detailed topics for 'quantified self' search

\begin{tabular}{|c|c|c|c|c|c|c|c|c|c|c|}
\hline & Health & Activity & Productivity & Privacy & Fashion & Other & Environment & Effects & $\begin{array}{c}\text { Personal } \\
\text { Tracking }\end{array}$ & Business \\
\hline Design & 8 & 2 & 3 & 2 & & 3 & 3 & 1 & 2 & 1 \\
\hline Business & 4 & 7 & 2 & 4 & & 1 & & & & 4 \\
\hline Gear & 4 & 11 & & & 1 & 2 & 3 & & & \\
\hline Science & 5 & & & & & & & & 1 & 1 \\
\hline Magazine & & 1 & & & & 1 & & & & 1 \\
\hline Security & & 1 & & 1 & & & & & & \\
\hline Sponsored & 4 & 1 & 2 & 5 & & 4 & & 3 & & 7 \\
\hline Undetermine & 3 & 3 & & 1 & 1 & 1 & & 2 & & 3 \\
\hline
\end{tabular}

When the table is examined, it is seen that the articles are most frequently marked with the 'design' key word. The word 'business' and 'gear' are other closely following keywords. From this data, it can be read that authors express and associate the concept of 'quantified self' with these words at first glance. 
The articles tagged with the word 'design' appear to have been written about a wide range of products. As for the articles marked by the keyword 'gear', they focus more on health related issues and activity tracking.

In the suggested subject headings, it is intended to give clues about the product or concept that is related to the subject in question. While 'activity tracking' refers to products and applications that help the individual to retain data about his / her physical features and activities (step, running, cycling, blood pressure etc.), in the heading of 'health related issues', a more comprehensive follow-up (medical issues, woman issues, sleep tracking, etc.) is implied. In the title of 'other', articles about sociality related devices were taken into consideration. The term 'environment' includes agricultural, personal environment, carbon footprint and other environmental factors. In the heading of 'effects', the psychological and sociological effects of devices and applications on humans and society are discussed. The term 'personal tracking' refers not only to a specific feature of a person, but also to almost every feature that can be captured and transformed into a data.

The next detailed examination (Table 5 and Table 6) was made on the basis of "self-tracking" term and examined 18 articles that did not appear in other searches.

Table 5. Article keywords and usage percentage for 'self-tracking' search

\begin{tabular}{|c|c|c|c|c|c|c|c|c|}
\hline & \multicolumn{7}{|c|}{ Article Topic } \\
\hline & Design & Business & Gear & $\begin{array}{c}\text { Scienc } \\
\mathrm{e}\end{array}$ & $\begin{array}{c}\text { Magazin } \\
\mathrm{e}\end{array}$ & Security & Sponsored & $\begin{array}{c}\text { Undetermine } \\
\mathrm{d}\end{array}$ \\
\hline Quantity & 3 & 2 & 3 & 1 & 3 & 1 & 3 & 2 \\
\hline Percentage & $\begin{array}{c}16.6 \\
\%\end{array}$ & $11.1 \%$ & $\begin{array}{c}16.6 \\
\%\end{array}$ & $5.5 \%$ & $16.6 \%$ & $5.5 \%$ & $16.6 \%$ & $11.1 \%$ \\
\hline
\end{tabular}

Table 6. Article keywords and detailed topics for 'self-tracking' search

\begin{tabular}{|c|c|c|c|c|c|c|}
\cline { 2 - 7 } \multicolumn{1}{c|}{} & Health & Activity & Privacy & Effects & Personal & Business \\
\hline Design & 1 & & & 1 & 1 & \\
\hline Business & 1 & & 1 & & & \\
\hline Gear & & 2 & & & & 1 \\
\hline Science & & 1 & & & & \\
\hline Magazine & 3 & 1 & & & & 2 \\
\hline Security & & 1 & 1 & & & \\
\hline Sponsored & & 2 & & 1 & & 1 \\
\hline Undetermined & & & 1 & & & 1 \\
\hline
\end{tabular}

Besides the mentioned key words from Wired magazine, which are the rows in Table 6, the term selftracking is examined cross the 6 headings that we suggested, namely health, activity, privacy, effects, personal, business. It can be seen that the articles that appear in this search are less both in number and in terms of subjects than in the quantified self study (Table 4).

Lastly, 10 articles that appeared in the 'lifelogging' search which were not common to other subjects were examined for content (Table 7 and Table 8).

Table 7. Article keywords and usage percentage for 'lifelogging' search

\begin{tabular}{|c|c|c|c|c|c|c|}
\hline & \multicolumn{5}{|c|}{ Article Topic } \\
\hline & Design & Business & Gear & Culture & Sponsored & Undetermined \\
\hline Quantity & 2 & 2 & 1 & 1 & 1 & 3 \\
\hline Percentage & $20 \%$ & $20 \%$ & $10 \%$ & $10 \%$ & $10 \%$ & $30 \%$ \\
\hline
\end{tabular}


The Turkish Online Journal of Design, Art and Communication - TOJDAC

ISSN: 2146-5193, April 2018 Volume 8 Issue 2, p. 329-339

Table 8. Article keywords and detailed topics for 'lifelogging' search

\begin{tabular}{|c|c|c|c|c|c|c|}
\multicolumn{1}{c|}{} & Activity & Privacy & Other & Effects & Personal & Business \\
\hline Design & & 1 & & & 1 & 1 \\
\hline Business & & 1 & & & & 2 \\
\hline Gear & 1 & & & & & \\
\hline Culture & & & 1 & & & \\
\hline Sponsored & & & 1 & 1 & 1 & \\
\hline Undetermined & & 1 & 1 & & 1 & \\
\hline
\end{tabular}

Comparing the three research results (focused on keywords quantified self, self tracking, lifelogging) in Table 4,6,8; it is concluded that when the keywords from Wired magazine and the headings that this study offers are cross examined for the sake of disposition of the detailed analysis of the three main terms of the study, it is also seen that the three terms quantified self, self-tracking, lifelogging are positively correlated. For example, the articles on which the concept of 'productivity' is highlighted include 'privacy issues'. Furthermore, it is also seen that the concept of 'privacy issues' is emphasized in the context of 'business' and in the articles that concern the production and consumption industry. Within this context, the devices that enable bosses to constantly monitor workers' 'productivity' have been subject of many articles (Metz, 2015; Finley, 2014; Flaherty, 2014; Enthoven, 2013; Finley, 2013; Drummond, 2012).

Wired articles are evaluating concept work and market-driven products in self-tracking practice. When looked at the contents, it is seen that a very large part of these articles are found with positive comments and predictions about the products. This positive approach is also a factor that allows the trend to develop and spread. Since 2009, the issue of health has become a subject for more articles each year. Yet, there are article's like Seidenberg's which is published in November 2014, raising attention to the dark side of data sharing in self-tracking. She rightfully asks, besides the transforming power of health data which is our most personal asset, acquired from genome-based therapeutics and diagnostics to pulse-monitoring and smart watches, 'why should we continue to share it?'. Yet surprisingly like most of the articles on the subject, she emphasizes privacy risks but still advocates the need of people to measure and share their data because of the potential for change in the health and pharmaceutical sectors and for the benefit of all humanity.

In the development of the digitalized self-tracking trend, it can be said that it is actually a loop feeding between industry/academy and Wired magazine. In the first years of the magazine, some people have been doing experiments on themselves and do-it-yourself devices that you can follow on your own. In the magazine, especially in the first years following the introduction of the term quantified self, some of the experiments that some people have done on themselves and the do-it-yourself devices that you can follow yourself are discussed. Then, from this concept that emerged in the business world, products and services that provide for the field have begun to emerge. Especially in 2012 and afterwards, the products that the industry reveals and the concepts that the academy put forward have begun to be the subjects of the magazine. The publication of the articles titled 'Review' and edited as an evaluation of certain products also started in 2012.

In fact, Wired magazine has a feature of being a medium to bring together both industry and academic environment and potential or existing users to discuss the needs and requirements. They are among the other media that serve this area because of the number of users they have reached. Because of those features, it can be said that Wired Magazine works as both a trend indicator and a trend innovator.

\section{CONCLUSION}

Self-tracking devices make data collection process easier and provide an effective tool for motivating users toward lifestyle change. The use of the products, which are designed in order for the individual to achieve a better physical, mental or emotional sense, have evolved in a form that can serve far more 
than individual purposes over time. For instance, there are mobile apps, scales, and activity trackers that beam data they collect to the cloud systems are helping doctors and hospitals to keep tabs on their patients and inform treatments. Yet the variety and amount of data required to work with the healthcare industry is not reached so far. In addition, insurance and electronic medical records companies are investing in and partnering with tech outfits which encourage consumers to use activity and health tracking tools and upload the data to their platforms. Besides the growing interest among institutions, however, digitalized self-tracking trend did not become mainstream trend, yet. The fact that the products available in the market are very expensive is enough for these products to be regarded as luxury (Tso, 2013). Thus, self-tracking devices are not yet trend in early majority but only accepted by the early adopters so far. It seems that in a foreseeable future the self-tracking technologies will be one of the rising trends all over the world and Wired Magazine, publishing pioneering articles on technological developments, conducting reviews on new products and applications and writing reports to anticipate new developments or negative situations in the future, leads the way for users. The fact that in every month about 30 million people are accessing through wired.com in addition to the printed issues giving this media a significant power. The present study conducted in this paper exemplifies the rising phenomenon of self-tracking technologies terminology.

As the last words on the subject of the self-tracking technologies, it is inevitable that the amount and the diversity of data obtained allows us to progress in academic field and product development industry. However, this aforementioned technologies carry some debatable aspects. The variety of products that have emerged to store and analyze our personal information actually brings with it the issue of privacy. For example, Jordan and Pfarr (2014) refer to 'a future where self-tracking harnesses a whole population's data to identify patterns and make meaningful recommendations'. Whether this seems promising or controversial, one of many another dimensions the quantified workplace could raise privacy issues where an employer measure everything about the employees' work lives under the vague category of performance assessment. The absence of any legal regulations on confidentiality of health data leads to the emergence of establishments that act as a marketplace for information. Hence, as the self-tracking phenomenon flourishes, legal regulations corresponding potential risks and abuses should follow in order to live the advantages of this new technologies for the greater good.

\section{REFERENCES}

Drummond, K. (2012a, February 03). Darpa Implants Could Track Your Stress Level 24/7 https://www.wired.com/2012/02/body-implants/ Access date: 07.01.17

Enthoven, D. (2013, May 14). Quantified Self? How About a Quantified Workplace? https://www.wired.com/insights/2013/05/quantified-self-how-about-a-quantified-workplace/ Access date: 07.01.17

Finley, K. (2013, April 17). What if Your Boss Tracked Your Sleep, Diet, and Exercise? https://www.wired.com/2013/04/quantified-work-citizen/ Access date: 07.01.17

Finley, K. (2014, May 19). Why Tech's Best Minds Are Very Worried About the Internet of Things. https://www.wired.com/2014/05/iot-report/ Access date: 07.01.17

Flaherty, J. (2014, July 22). A Startup Creating a Hyper-Smart Office That Tracks Everything https://www.wired.com/2014/07/when-the-internet-of-things-meets-office-space/ Access date: 07.01.17

Gertenbach, L., \& Mönkeberg, S. (2016). Lifelogging and Vital Normalism. In Lifelogging (pp. 25-42). Springer Fachmedien Wiesbaden.

https://www.wired.com/2014/04/forget-the-quantified-self-we-need-to-build-the-quantified-us/Access date: 06.01.17

Pfarr, N. \& Jordan, M., (2014). Forget the Quantified Self. We Need to Build the Quantified Us. https://www.wired.com/2014/04/forget-the-quantified-self-we-need-to-build-the-quantified-us/ Access date: 06.01.17

Krynsky, M. (2010, December 29). The Emergence of Lifelogging and The Quantified Self. http://lifestreamblog.com/the-emergence-of-lifelogging-and-the-quantified-self/ Access date: 17.03.17

Submit Date: 12.10.2017, Acceptance Date: 15.03.2018, DOI NO: 10.7456/10802100/013

Research Article - This article was checked by Turnitin

Copyright $\odot$ The Turkish Online Journal of Design, Art and Communication 
Lupton, D. (2012). M-health and health promotion: The digital cyborg and surveillance society. Social Theory \& Health, 10(3), 229-244.

Lupton, D. (2013). Understanding the human machine [Commentary]. IEEE Technology and Society Magazine, 32(4), 25-30

Lupton, D. (2014, December). Self-tracking cultures: towards a sociology of personal informatics. In Proceedings of the 26th Australian Computer-human interaction conference on designing futures: The future of design (pp. 77-86). ACM.

Lupton, D. (2016). You are your data: Self-tracking practices and concepts of data. In Lifelogging (pp. 61-79). Ed. Stefan Selke, Springer

Metz, C. (2015, March 04). A Smartwatch App That Lets Your Boss Track You Constantly https://www.wired.com/2015/03/ready-social-smartwatch-quantified-work-app/Access date: 07.01.17

National Intelligence Council, (2008). Disruptive Technologies Global Trends 2025. Six Technologies with Potential Impacts on US Interests Out to 2025. http://www.fas.org/irp/nic/disruptive.pdf Access date: 09.03.2017

Peng, W., Kanthawala, S., Yuan, S., \& Hussain, S. A. (2016). A qualitative study of user perceptions of mobile health apps. BMC Public Health, 16(1), 1158.

Quantified Self self guide to self-tracking tools, (2017). Available online: http://quantifiedself.com/guidel Access date: 09.03.2017

Seidenberg, B. (2014, November 06). You Should Share Your Health Data: Its Value Outweighs the Privacy Risk https://www.wired.com/2014/11/on-sharing-your-medical-info/ Access date: 12.03.2017

Selke, S. (Ed.). (2016). Lifelogging: Digital self-tracking and Lifelogging-between disruptive technology and cultural transformation. Springer

Sellen, A. J., \& Whittaker, S. (2010). Beyond total capture: a constructive critique of lifelogging. Communications of the ACM, 53(5), 70-77.

Swan, M. (2013). The quantified self: Fundamental disruption in big data science and biological discovery. Big Data, 1(2), 85-99.

Tarde, G. (1903). The Laws of Imitation. New York: Henry Holt and Company.

The National Institute of Mental Health (NIMH). Technology and the Future of Mental Health Treatment https://www.nimh.nih.gov/health/topics/technology-and-the-future-of-mental-healthtreatment/index.shtml Access date: 11.12.2016

Tso, R.L. (2013, September 12). Your 'Quantified-Self': Are Wearable Technologies Just a Luxury for the Upper-Class? https://www.wired.com/insights/2013/09/your-quantified-self-are-wearabletechnologies-just-a-luxury-for-the-upper-class/ Access date: 06.01.2017

Winchester, H. (2015). A brief history of wearable tech. https://www.wareable.com/wearable-tech/abrief-history-of-wearables Access date: 06.01.17

Wired Magazine (2009). https://www.wired.com/about Access date: 15.01.17

Wolf, G. (2009, June 22). Know Thyself: Tracking Every Facet of Life, from Sleep to Mood to Pain, 24/7/365 https://www.wired.com/2009/06/lbnp-knowthyself/Access date: 06.01.17

Wolf, G. (2011, March 03). What is The Quantified Self? http://quantifiedself.com/2011/03/what-isthe-quantified-self/ Access date: 16.01.17

Submit Date: 12.10.2017, Acceptance Date: 15.03.2018, DOI NO: 10.7456/10802100/013

Research Article - This article was checked by Turnitin

Copyright (C) The Turkish Online Journal of Design, Art and Communication 